Ángulo Recto. Revista de estudios sobre la ciudad como espacio plural ISSN: 1989-4015

\section{Jardín inglés}

Antonio Jiménez Millán

Entre dos mundos la tregua que no tenemos

Pier Paolo Pasolini

A Javier Egea

Es una luz extraña la de este amanecer en el Paseo de Reding, un vago resplandor entre el silencio de las playas desiertas, dormidas como brasas.

El viento mueve

los árboles del cementerio inglés, su olvidada quietud de violetas y óxido. Recuerdas los detalles de una historia que ella te contó. Era muy joven y vio cómo llegaban

los muertos de un naufragio, una fragata hundida junto al puerto, en una noche infame,

llena de gritos y destellos leves de luces bajo un cielo de tormenta. Desde la soledad, imaginas ahora a aquellos hombres que yacen en las tumbas: vinieron de la bruma de otro siglo, del tráfico de lentos carruajes, de navíos en aguas encrespadas, de las bodegas húmedas y los mástiles rotos, ajenos a la calma de los muelles distantes del invierno.

\section{Inscripciones}

borradas por la lluvia y el verdín, nombres perdidos, velados por la escarcha en un sueño de sauces y jazmines, castaños, buganvillas, cipreses que dan sombra a las estatuas.
Y recuerdas también unos versos de Shelley:

"Mientras cobije

el cielo azul de Italia su reposo

y el rocio refresque todavía

su sueño, no, no queráis despertarlo..."

Hablaban de John Keats, muerto en Roma, de la nostalgia y de la claridad que nos alejan de una tierra estéril, vencida por el frío.

El viento de levante va esparciendo las hojas secas

de principios de otoño y la historia parece detenida en la solemnidad de este jardín, tan cerca de escombreras y derribos. Piensas en tu destino de extranjero y buscas una tregua entre dos mundos: son antiguas imágenes sin orden, restos de niebla que el calor deshace, edificios manchados donde nadie te espera.

Sigues ahí, al lado de los muros del cementerio inglés, ignorando las voces que comienzan a escucharse a lo lejos. Ya no importa aquel cuerpo que estaba junto a ti hace unas horas, porque la intensidad es sólo un espejismo, la noche una emboscada, la costumbre una forma de la muerte. 
Es una luz extraña la de este amanecer, un brillo de navaja abierta en el asfalto que deja atrás un rostro a la deriva mirando a la ciudad, desvaneciéndose como si fuera humo,

como si el tiempo ya lo hubiera destruido.

(Ciudades. Antología 1980-2015, Sevilla, Renacimiento, 2016) 